\title{
The Impact of Migration on Capital Markets
}

\author{
Thomas Poufinas*, George Galanos \\ Department of Economics, Democritus University of Thrace, Komotini, Greece \\ Email: ^tpoufina@econ.duth.gr, ggalanos@econ.duth.gr
}

How to cite this paper: Poufinas, T. and Galanos, G. (2018) The Impact of Migration on Capital Markets. Theoretical Economics Letters, 8, 2550-2558. https://doi.org/10.4236/tel.2018.811163

Received: June 27, 2018

Accepted: August 21, 2018

Published: August 24, 2018

Copyright $\odot 2018$ by authors and Scientific Research Publishing Inc. This work is licensed under the Creative Commons Attribution International License (CC BY 4.0).

http://creativecommons.org/licenses/by/4.0/

\begin{abstract}
Migration is a topic that has always attracted the interest of researchers, policy makers, politicians and the simple people as well, primarily because of its social labor and economic dimensions. In this paper we attempt to identify what may be the impact of migration to the capital markets of the countries that receive the migrants. To do that we use an econometric approach, employing linear regression in order to investigate the relationship between the immigration flows, as measured by the number of immigrants and the capital market variables of interest. These are market capitalization (as a percent of GDP and USD billion), bank deposits (as a percent of GDP and USD billion), public debt (as a percent of GDP and USD billion) and net public debt (in USD billion). We use the Stata econometric software to run these linear regressions with Ordinary Least Squares (OLS). We find evidence that the number of immigrants could have a positive impact to the capital markets of the recipient country, as it is positively correlated with the market capitalization, the bank deposits and the public debt.
\end{abstract}

\section{Keywords}

Migration, Capital Market, Stock Market, Enterprises

\section{Introduction}

The migration phenomenon is a complex one and needs to be analyzed from many aspects. Economists were the first to develop theories on immigration by analyzing its causes and effects. According to the neoclassic economic theory, the wage imbalances among the countries that trigger float increase will continue to exist whereas a new international equilibrium is created where real wages are of the same level in all countries. The first is a low-skilled workforce flow from low-wage countries to high-wage countries. The second is a flow of capital from countries with high wages to countries with low wages. This capital flow mainly involves high labor-intensive industrial capital and will be accompanied by a 
highly skilled labor force of immigrants. The mechanism leading to this equilibrium is presented by Öberg [1]; both net labor migration and net capital flows will be equal to zero when a new balance is achieved. According to this mechanism in the long run market forces tend to create a new equilibrium where wages have the same levels in all regions, provided that the mobility of capital and labor is allowed. Consequently, from this point of view, the net international migration of labor is a time-related phenomenon.

The European Union is in front of a crossroad, facing on one hand an unprecedented wave of refugees and/ or migrants and on the other hand a fear that some of its member states could leave it. Brexit will eventually take place, which means that people or enterprises domiciled in Great Britain may want to move/go back to a member state, creating also some intra European Union migration flow of human as well as fiscal capital. Migrants not only increase the population of a country but may very well contribute to the labor market, the social security schemes and the capital markets of the country they join, starting from the banking sector and extending to the stock and bond markets. At the same time though, they may choose to invest or direct part of their income back to their home country. This depends on the country of origin and the feasibility it provides for such a return of funds. In other cases, they may decide to temporarily save money and repatriate them upon their return, potentially at retirement. In this new environment some of the countries of the European Union will find themselves accepting people and enterprises from the Great Britain, but also from other parts of the world. This may create "new" financial centers within the European Union, some of them smaller and some of them bigger.

In this paper we try to identify what may be the impact of migration to the capital markets of the countries that receive the immigrants.

\section{Literature Review}

Even though the neoclassical economic theory is used to explain the migratory flows among countries its use is critical regarding internal migration. Contrary to international migration, internal migration is more resilient to policy. Today, the neoclassical economic theory cannot be used to explain the international immigration flows within the European Union because these flows are less influenced by political constraints. Keynesian economic theory sets out a different view from the neo-classical view of (international) migration. According to the Keynesian theory, labor supply also depends on the increase in nominal wages, not just on real wages. This distinction stems from different points of view on the role of money in the economy.

According to the neoclassical point of view, money is only a means of exchange. The Keynesian view is different, because, according to it, money is not only a means of exchange, but also a means of saving. Due to this last characteristic of money, potential migrants are attracted to regions with a high nominal wage growth. In addition, the intention to re-emigrate or to send remittances 
further increase the importance of nominal wage levels relative to real wage levels. As a result, there may not be a new international equilibrium, as neoclassical economic theory assumes. Nevertheless, in Keynesian theory, migration is also a mechanism for regaining balance.

The binary approach to the labor market divides the labor market into a primary and a secondary segment. The primary sector is characterized by the high-capital production method, while the secondary sector is characterized by a high-labor force production process. Qualified workers in the primary sector who have been trained to work with state-of-the-art capital goods have better social status, higher income and better working conditions than unskilled workers in the secondary sector. Labor market jobs are almost always in the secondary sector.

Scientific research on the economic effects of migration has mainly focused on its impact on recipient countries, more specifically for the United Kingdom, a study of the impact of immigrants on the economy was made by the House of Lords, and in particular by the Committee dealing with economic issues. (House of Lords, 2008). More specifically, it is reported that immigration has benefits for both migrant families and the countries they come from, as income flows to their countries. However, the impact that the immigrants have on the Gross Domestic Product, as they mention, is very small and insignificant, whether being positive or negative. In general, as the study implies, in this economic frame from immigration there are losers and winners. The winners are immigrants, their employers, as well as consumers who enjoy lower prices. The UK's low-paid workers are losers, since they are competing in the labor market directly with migrants.

Studies on the US lead on similar findings; the economic impact caused by migrants within the country is low. This, as supported by the article by LaLonde and Topel [2], means that emigration generally has a very small effect on the distribution of income. Borjas's studies [3] [4] have not shown that migration to the United States dramatically affects unemployment. Bean et al. [5] showed that in the case of the United States, the use of illegal immigrants had a small negative impact on the salaries of local workers. Card [6] also found that in the case of the United States, the entry of migrants adversely affects the employment of locals, but has very little effect on salary levels. In the case of Europe, there is a study by Winkelman and Zimmermann [7] which proves that the impact of immigration on unemployment is not significant. It is believed that in Europe migrants are used as a flexible reserve in cases where local labor mobility is limited [8] [9] [10].

At the same time, many econometric studies have indeed shown that when migratory flows emerge, they coincide with strong wage differentials among countries, but at the same time they have shown that strong wage differences worldwide do not necessarily stimulate migratory movements. Also, the neoclassical approach does not interpret the current limited movement from Third Countries to the industrialized countries of the West, despite the dramatic wage 
differences between them. There is also a plethora of empirical examples challenging a series of neoclassical hypotheses, such as full and in depth information of candidate migrants, the certainty of the immigration decision and its origin, while others demonstrate the strengthening of other factors for taking the immigration decision (e.g., the existence of migratory networks).

In addition to certain surveys, the importance of relative income as a catalytic variable for the explanation of the immigration decision is expressed, while in others factors such as the fact that immigration decision is not taken individually is not taken into account, while others project the theory of dualism in the labor market which attributes international migration to the long-standing demand for migrant workers inherent in the economic structure of developed countries. This persistent demand for migrant workers stems from four fundamental structural features of industrially developed societies (structural inflation, incitement problems, economic dualism, demographics of labor supply) that create and sustain the segmentation of the job market. At the same time, Jackson [11] projected a negative impact; in particular, he stated that the negotiating power of the working class, due to the existence of the reserve army (the surplus workforce), has as its main effect the restraint of the remuneration of labor to levels lower than those that the growth should have formed, and we could not omit the fact of the bloom of the shadow economy leading to a reduction of the state profits. Due to the fact that unskilled immigrants do not come under the collective labor contract, the employer's non-payment of social security contributions to the state is reinforced, with a significant burden of the state budget, with government revenue being reduced.

Pedersen [12] studying the experience of Germany, found that immigrants are generally concentrated in the suburbs of large urban centers. Boeri and Bruecker [13] studying the impact of legal immigration due to EU expansion on the labor markets of the EU countries, found that both international trade and the movement of capital do not lead to significant equalization of producer prices, including wages. As a result, the impact on the wages of EU countries, even on those of Austria and Germany, which are expected to accept much more immigrants than other countries, will be very small. Straubhaar and Golder [14] [15] found that in the case of Switzerland the impact of immigrants on the Swiss economy was negative. Hartog and Zorlu [16] expanding the model of Altonji and Card [6], which analyzed the impact of immigrants at the labor markets, studied the way that the use of immigrants affects the wages of locals in the Netherlands, the United Kingdom and in Norway.

However, the impact of migration on the capital markets has not been widely studied. This is the topic that we address in this paper.

\section{Data, Variables and Methodology}

\subsection{Data}

Our dataset comes from Eurostat [17] as far as the number of immigrants is 
concerned, from the World Bank [18] [19] with regards to the market capitalization and from the Helgi Library when it comes to bank deposits [20] [21] and public debt [22] [23] [24]. We used data for the 32 countries of Europe for which migration figures were available. These are Austria, Belgium, Bulgaria, Croatia, Cyprus, Czech Republic, Denmark, Estonia, Finland, France, Germany, Greece, Hungary, Iceland, Ireland, Italy, Latvia, Liechtenstein, Lithuania, Luxembourg, Malta, Netherlands, Norway, Poland, Portugal, Romania, Slovakia, Slovenia, Spain, Sweden, Switzerland and the United Kingdom. As we are interested in the years after 2012, we used the country averages for the years after 2012. More precisely, for the number of immigrants we employed the average for the years 2012-2015, for market capitalization the average for the years 2012-2016, for bank deposits in USD the average for the years 2012-2013 and in percent of GDP the average for the years 2012-2014. Finally, for the public debt we calculated the average for the years 2012-2014. In all cases the availability of data determined the averaging.

\subsection{Variables}

The number of immigrants, calculated as the average total number of long-term immigrants arriving into the reporting country during the reference year for the years 2012-2016, as derived from Eurostat [17] is our independent variable.

The market capitalization of listed domestic companies as a percent of GDP and in USD billion, taken as the average of the market capitalization of listed domestic companies (as a percent of GDP and in USD billion) for the years 2012-2016, as taken from the World Bank [18] [19] are two of our dependent variables.

The bank deposits as a percent of GDP and in USD billion, derived as the average for the years 2012-2014 and 2012-2013 respectively, as taken from the Helgi Library [20] [21] are our other two dependent variables.

The public debt as a percent of GDP and in USD billion, as well as the net public debt in USD billion, found as the average for the years 2012-2014, as taken from the Helgi Library are our last three dependent variables.

The rationale behind the choice of these variables is almost straightforward; we attempt to identify, whether the immigration flows in a country have a relation with the capital markets of that country. For this, we examine initially the bank deposits, then the equity market and finally the bond market, assuming that higher public debt leads to a bigger bond market.

\subsection{Methodology}

We use linear regression to investigate the relationship between the immigration flows and the capital market variables of interest. We use the Stata econometric software to run these linear regressions with Ordinary Least Squares (OLS). We use White's test to detect potential heteroskedasticity and we use Robust Standard Errors to tackle it when present. The regressions we run use one dependent 
and one independent variable. The general form of the regression equation is:

$$
y=\beta_{0}+\beta_{1} \cdot x+u
$$

where $y$ is one of the capital market variables described above, i.e. market capitalization(as a percent of GDP and USD billion), bank deposits (as a percent of GDP and USD billion), public debt (as a percent of GDP and USD billion) and net public debt (in USD billion). The number of immigrants is denoted by $x$.

\section{Results and Implications}

From the regression of the number of immigrants with the market capitalization we realize that the first is positively correlated with the second at all significance levels, when we consider the market capitalization in USD billion. This is shown in regression 2 in Table 1 below. As a matter of fact the coefficient is 0.0017814 , which is positive. However, there seems to be no statistical significance when we consider the market capitalization as a percent of GDP.

When regressing the number of immigrants with the bank deposits, we observe a similar result. The number of immigrants is positively correlated with the bank deposits in USD billion at all significance levels. There is no statistical significance when the bank deposits as a percent of GDP are considered.

Finally, the regression of the number of immigrants with the public debt shows a positive correlation at all significance levels when the public debt amount or the net public debt amount in USD billion is used. Similarly, there seems to be no statistical significance when the public debt as a percent of GDP is used.

Table 1. Regression summary.

\begin{tabular}{|c|c|c|c|c|c|c|c|}
\hline Variables/Regressions & (1) & (2) & (3) & (4) & (5) & (6) & (7) \\
\hline \multicolumn{8}{|l|}{ Dependent Variables } \\
\hline market capitalization (\% of GDP) & $\mathrm{x}$ & & & & & & \\
\hline market capitalization (USD billion) & & $\mathrm{x}$ & & & & & \\
\hline bank deposits (USD billion) & & & $\mathrm{X}$ & & & & \\
\hline bank deposits (\% of GDP) & & & & $\mathrm{x}$ & & & \\
\hline public debt (USD billion) & & & & & $\mathrm{x}$ & & \\
\hline public debt (\% of GDP) & & & & & & $\mathrm{x}$ & \\
\hline net public debt (USD billion) & & & & & & & $\mathrm{X}$ \\
\hline \multicolumn{8}{|l|}{ Independent Variables } \\
\hline number of immigrants & $\begin{array}{c}0.0000439 \\
(1.05)\end{array}$ & $\begin{array}{c}0.0017814^{* * *} \\
(3.52)\end{array}$ & $\begin{array}{c}0.0053673^{* * *} \\
(4.21)\end{array}$ & $\begin{array}{c}-8.45 e-06 \\
(-0.08)\end{array}$ & $\begin{array}{c}0.0038334^{* * *} \\
(5.94)\end{array}$ & $\begin{array}{c}0.0000431 \\
(1.24)\end{array}$ & $\begin{array}{c}0.0031013^{* * *} \\
(4.24)\end{array}$ \\
\hline Constant & $\begin{array}{c}25.70032^{* *} \\
(2.68)\end{array}$ & $\begin{array}{c}41.9346 \\
(0.90)\end{array}$ & $\begin{array}{c}93.98644 \\
(0.81)\end{array}$ & $\begin{array}{c}129.5421^{* * *} \\
(5.32)\end{array}$ & $\begin{array}{c}15.13902 \\
(0.27)\end{array}$ & $\begin{array}{c}61.81463^{* * *} \\
(7.75)\end{array}$ & $\begin{array}{c}-62.83149 \\
(-0.81)\end{array}$ \\
\hline Observations & 32 & 32 & 32 & 32 & 32 & 32 & 32 \\
\hline Adjusted R-squared & 0.0031 & 0.3968 & 0.7116 & -0.0331 & 0.7569 & 0.0167 & 0.5969 \\
\hline
\end{tabular}

Notes: $\mathrm{t}$-values in parenthesis; ${ }^{* *}$ statistically significant at the $1 \%$ level; ${ }^{* *}$ statistically significant at the $5 \%$ level; ${ }^{\star}$ statistically significant at the $10 \%$ level. 
We tested the above regressions that showed statistical significance for heteroskedasticity. To detect this we used White's test to find that regressions 2, 3, 5 and 7 (Table 1) seem to exhibit heteroskedasticity. We corrected it by using the robust standard errors approach.

Our findings indicate that there seems to be a definite link between the immigrant flows in a given European country and the size of its market capitalization, bank deposits and public debt, with the latter acting as a proxy of the bond market. This means that immigrants may very well contribute to the capital market growth of the countries receiving them. Consequently, would a member state decide to leave the European Union and its residents decide to move to another member state, there could be a benefit to the capital markets of the receiving states. Moreover, if a member state creates the conditions to receive more such immigrants, then it can foster the creation of a "new" financial center within the European Union.

A country needs to therefore clearly include among the benefits of receiving immigrants the indicated positive impact on its capital markets and incorporated it in its policy making when balancing the pros and the cons of accepting immigrants.

Our research has some limitations. One is that we did not have data for the departing countries. Another is that our dataset did not allow for the distinction between refugees and immigrants. One route to overcome this would be to assume that at a certain point of time the majority of these refugees will settle as immigrants to some countries; it would then be no surprise to eventually see a positive effect to the capital markets of these countries. An alternative route would be to study the impact of refugees separately as soon as we gain access to appropriate data.

\section{Conclusions}

In this paper we focused on the effect of migration to the capital markets of the countries that receive immigrants. We did not have data to investigate the effect to the capital markets of the countries from which they depart. We therefore leave this for future research. Moreover, we were not able to access data that distinguish between immigrants and refugees. Investigating the impact of refugees is a topic that is left for further research. In addition, the study of the consequences to the entrepreneurial life of the receiving countries, as well as to the labor market and to the social security schemes will take place in the future.

The immigration flows in the countries of the European Union have been once and again a topic of interest. This is because an appropriate policy needs to be put in place so that the immigrants properly settle in the different members of the European Union. It seems that emphasis has been given in the social aspect, as well as on the capacity of the receiving countries to absorb these migrants. Of course the trigger point was the big number of waves of refugees. Policy makers try to facilitate the decision making on the reception of immigrants to a certain 
country and are thus looking for the positive and negative consequences of receiving immigrants.

The economic consequences are being considered as well. Immigrants provide labor but they also draw part of the resources and the capital of the country. The latter may create different sentiments to people, both the citizens of the country as well as the immigrants. Our article contributes significantly in this direction as it considers a different perspective; this of the potential relation between migration and the capital markets. In this paper we were able to demonstrate that the number of immigrants could have a positive impact to the capital markets of the recipient country. We did that by showing that the number of immigrants in a country is positively correlated with the market capitalization, the bank deposits and the public debt, with the latter considered as an indicator of the size of the bond market.

Consequently, we offer a new angle of viewing migration, as we go beyond the usual consideration of the migration phenomenon and discover that it can have benefits for the capital markets that cannot be ignored.

\section{Conflicts of Interest}

The authors declare no conflicts of interest regarding the publication of this paper.

\section{References}

[1] Oberg, S. (1997) Theories on Inter-Regional Migration: An Overview. In: Blotevogel, H.H. and Fielding, A.J., Eds., People, Jobs and Mobility in the New Europe, John Wiley \& Sons Inc., New York, 23-48.

[2] LaLonde, R.J. and Topel, R.H. (1997) Economic Impact of International Migration and the Economic Performance of Migrants. In: Rosenzweig, M.R. and Stark, O., Eds., Handbook of Population and Family Economics, Volume 1, Part B Elsevier Science B.V., 799-850.

[3] Borjas, G. (1990) Friends or Strangers: The Impact of Immigrants on the US Economy. Basic Books, New York.

[4] Borjas, G. and Bratsberg, B. (1993) Who Leaves? The Outmigration of the Foreign-Born. Mimeo. (University of California at San Diego, San Diego).

[5] Bean, F.D., Vernez, G. and Keely, C.B. (1989) Opening and Closing the Doors: Evaluating Immigration Reform and Control. Urban Institute Press, Washington DC.

[6] Altonji, J.G. and Card, D. (1991) The Effects of Immigration on the Labor Market Outcomes of Less-Skilled Natives. In: Abowd, J.M. and Freeman, R.B., Eds., Immigration, Trade, and the Labor Market, The University of Chicago Press, Chicago.

[7] Winkelmann, R. and Zimmermann, K. (1992) Ageing, Migration and Labour Mobility. Centre for Economic Policy Research, London. http://www.cepr.org/active/publications/discussion_papers/dp.php?dpno=706

[8] Zimmermann, K.F. (1995) Tackling the European Migration Problems. Journal of Economic Perspectives, 9, 45-62. https://doi.org/10.1257/jep.9.2.45

[9] Zimmermann, K.F. (1995) European Migration: Push and Pull. International Regional Science Review, 19, 95-128. 
[10] Zimmermann, K. (1994) European Migration: Push and Pull. Presented at the Annual Bank Conference on Development Economics, World Bank, Mimeo. (University of Munich, Munich).

[11] Jackson, J.A. (1986) Migration. Longman, NY, 79-80.

[12] Pedersen, P.J., Pytlikova, M. and Smith, N. (2008) Selection and Network Effects-Migration into OECD Countries 1990-2000. European Economic Review, 52, 1160-1186. https://doi.org/10.1016/j.euroecorev.2007.12.002

[13] Boeri, T. and Bruecker, H. (2000) The Impact of Eastern Enlargement on Employment and Wages in the EU Member States. Report to the European Commission.

[14] Golder, S.M. and Straubhaar, T. (1999) Empirical Findings on the Swiss Migration Experience. IZA Discussion Paper No. 40.

[15] Golder, S.M. and Straubhaar, T. (1999) Discrimination in the Swiss Labor Market: An Empirical Analysis. CEPR Discussion Paper No. 2100.

[16] Zorlu, A. (2002) Absorption of Immigrantsin European Labour Markets. The Netherlands, United Kingdom and Norway. Dissertation: University of Amsterdam, Tinbergen Institute Research Series, 279.

[17] Eurostat (2017) Total Number of Long-Term Immigrants Arriving into the Reporting Country during the Reference Year. http://ec.europa.eu/eurostat

[18] The World Bank (2017) Market Capitalization of Listed Domestic Companies (Current US\$). https://data.worldbank.org/indicator/CM.MKT.LCAP.CD?view=chart

[19] The World Bank (2017) Market Capitalization of Listed Domestic Companies (\% of GDP). https://data.worldbank.org/indicator/CM.MKT.LCAP.GD.ZS?view=chart

[20] Helgi Library (2017) Bank Deposits (As \% of GDP). https://www.helgilibrary.com/indicators/bank-deposits-as-of-gdp/

[21] Helgi Library (2017) Bank Deposits (USD). https://www.helgilibrary.com/indicators/bank-deposits-usd/

[22] Helgi Library (2017) Net Public Debt (USD). https://www.helgilibrary.com/indicators/net-public-debt-usd/

[23] Helgi Library (2017) Public Debt (As \% of GDP). https://www.helgilibrary.com/indicators/public-debt-as-of-gdp/

[24] Helgi Library (2017) Public Debt (USD). https://www.helgilibrary.com/indicators/public-debt-usd/ 